\title{
BMJ
}

\section{Diagnostic value of laboratory tests in identifying serious infections in febrile children: systematic review}

\author{
Ann Van den Bruel, academic clinical lecturer, ${ }^{1}$ Matthew J Thompson, associate professor, ${ }^{1,2}$ Tanya Haj- \\ Hassan, medical student, ${ }^{3}$ Richard Stevens, senior statistician, ${ }^{1}$ Henriette Moll, professor, ${ }^{4}$ Monica \\ Lakhanpaul, senior lecturer, ${ }^{5}$ David Mant, emeritus professor ${ }^{1}$
}

${ }^{1}$ Department of Primary Health Care, University of Oxford, UK

${ }^{2}$ Department of Family Medicine, Oregon Health and Sciences University, USA

${ }^{3}$ University of Oxford, UK

${ }^{4}$ Erasmus MC-Sophia Children's Hospital, Rotterdam, Netherlands

${ }^{5}$ Health Education Research and Development Unit, Department of Medical and Social Care

Education, University of Leicester, UK

Correspondenceto:A VandenBruel ann.vandenbruel@dphpc.ox.ac.uk

Cite this as: $B M J$ 2011;342:d3082 doi:10.1136/bmj.d3082

\section{ABSTRACT}

Objective To collate all available evidence on the diagnostic value of laboratory tests for the diagnosis of serious infections in febrile children in ambulatory settings.

Design Systematic review.

Data sources Electronic databases, reference tracking, and consultation with experts.

Study selection Studies were selected on six criteria: design (studies of diagnostic accuracy or deriving prediction rules), participants (otherwise healthy children and adolescents aged 1 month to 18 years), setting (first contact ambulatory care), outcome (serious infection), features assessed (in first contact care), and data reported (sufficient to construct a $2 \times 2$ table).

Data extraction Quality assessment was based on the quality assessment tool of diagnostic accuracy studies (QUADAS) criteria. Meta-analyses were done using the bivariate random effects method and hierarchical summary receiver operating characteristic curves for studies with multiple thresholds.

Data synthesis None of the 14 studies identified were of high methodological quality and all were carried out in an emergency department or paediatric assessment unit. The prevalence of serious infections ranged from $4.5 \%$ to $29.3 \%$. Tests were carried out for $\mathrm{C}$ reactive protein (five studies), procalcitonin (three), erythrocyte sedimentation rate (one), interleukins (two), white blood cell count (seven), absolute neutrophil count (two), band count (three), and left shift (one). The tests providing most diagnostic value were $C$ reactive protein and procalcitonin. Bivariate random effects meta-analysis (five studies, 1379 children) for $C$ reactive protein yielded a pooled positive likelihood ratio of 3.15 (95\% confidence interval 2.67 to 3.71 ) and a pooled negative likelihood ratio of 0.33 ( 0.22 to 0.49$)$. To rule in serious infection, cut-off levels of $2 \mathrm{ng} / \mathrm{mL}$ for procalcitonin (two studies, positive likelihood ratio $13.7,7.4$ to 25.3 and $3.6,1.4$ to 8.9 ) and $80 \mathrm{mg} / \mathrm{L}$ for $\mathrm{C}$ reactive protein (one study, positive likelihood ratio $8.4,5.1$ to 14.1 ) are recommended; lower cut-off values of $0.5 \mathrm{ng} / \mathrm{mL}$ for procalcitonin or $20 \mathrm{mg} / \mathrm{L}$ for $C$ reactive protein are necessary to rule out serious infection. White blood cell indicators are less valuable than inflammatory markers for ruling in serious infection (positive likelihood ratio 0.87-2.43), and have no value for ruling out serious infection (negative likelihood ratio 0.61-1.14). The best performing clinical decision rule (recently validated in an independent dataset) combines testing for $C$ reactive protein, procalcitonin, and urinalysis and has a positive likelihood ratio of 4.92 (3.26 to 7.43 ) and a negative likelihood ratio of 0.07 (0.02 to 0.27 ).

Conclusion Measuring inflammatory markers in an emergency department setting can be diagnostically useful, but clinicians should apply different cut-off values depending on whether they are trying to rule in or rule out serious infection. Measuring white blood cell count is less useful for ruling in serious infection and not useful for ruling out serious infection. More rigorous studies are needed, including studies in primary care, to assess the value of laboratory tests alongside clinical diagnostic measurements, including vital signs.

\section{INTRODUCTION}

We recently published a systematic review on the diagnostic value of presenting clinical features in identifying serious infection in children. ${ }^{1}$ This review identified several important red flags; it also confirmed that consideration of symptoms and signs alone often results in residual diagnostic uncertainty - with the risk of serious infection being too high to ignore yet too low to justify hospital admission. The diagnostic uncertainty that clinicians are left with after clinical assessment was confirmed in a recent, large cohort study, where even a complex clinical decision rule involving 28 clinical features could not provide perfect discrimination. $^{2}$

In situations with a significant risk of rapid progression of illness, or where further refining of the risk estimate could either rule out serious infection or influence a decision to admit to hospital or treat with antibiotics, ${ }^{3}$ clinicians often try to increase diagnostic certainty by measuring the white blood cell count or blood levels of inflammatory markers. Although in a hospital setting these tests are normally carried out in a laboratory, many are now available as point of care tests, which give an immediate result and can be used in ambulatory care settings. 
Earlier systematic reviews have assessed the value of one or two laboratory tests in children only ${ }^{4}$ or in children and adults ${ }^{5-7}$ for the diagnosis of various outcomes, such as distinguishing viral pneumonia from bacterial pneumonia ${ }^{8}$ or parenchymal involvement in children admitted with a urinary tract infection. ${ }^{9} \mathrm{We}$ reviewed the diagnostic value of all possible blood tests for ruling in and ruling out serious infection in children in ambulatory settings and their added value after clinical signs and symptoms, using the same rigorous methods as in our previous review. ${ }^{1}$

\section{METHODS}

The methods of our review have been published in detail elsewhere. ${ }^{1}$ Briefly, we searched the literature electronically in Medline, Embase, DARE, and CINAHL, using search terms relating to serious infections, children, clinical and laboratory tests, and ambulatory care (see web extra annex 1). In addition, a snowballing strategy included checking the reference lists of included studies, systematic reviews, and relevant National Institute for Health and Clinical Excellence guidelines, ${ }^{1011}$ and consultation with experts.

Two independent reviewers (AVDB and TH-H) carried out the selection. A third independent reviewer (MJT) resolved discrepancies. Studies were selected if they assessed diagnostic accuracy of clinical features or laboratory tests in previously well children and adolescents between 1 month and 18 years of age presenting to ambulatory care (defined as general or family

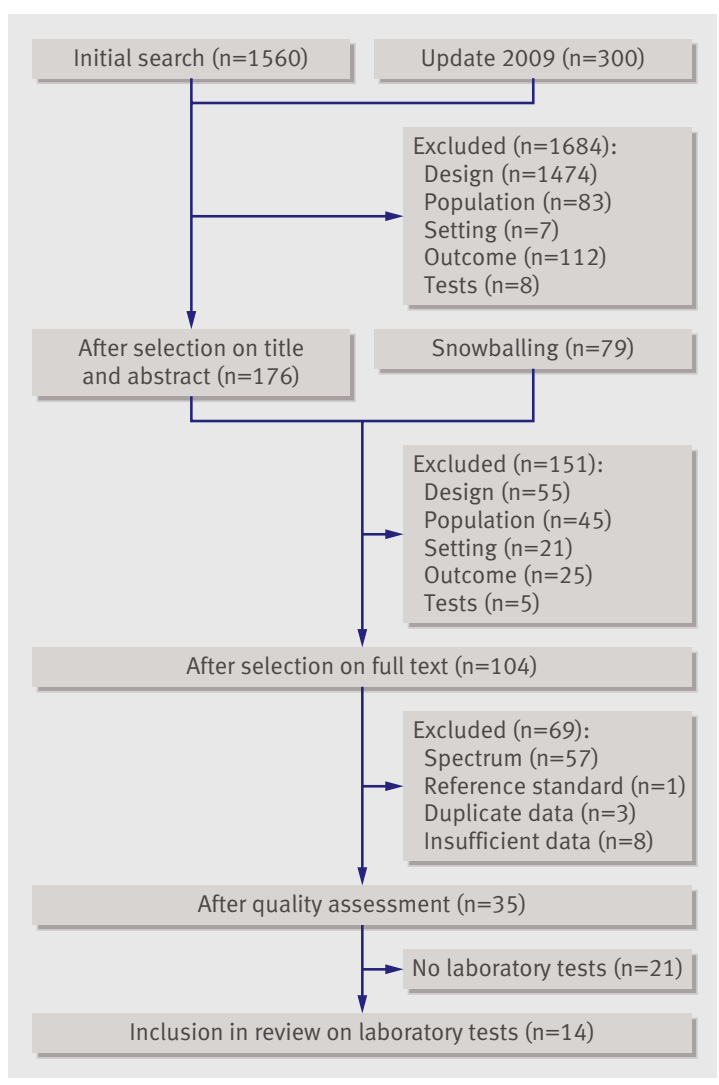

Fig 1 | Flow of papers through study practice, paediatric outpatient clinics, paediatric assessment units, or emergency departments) in Europe, Canada, the United States, Australia, New Zealand, and Japan.

Serious infections were defined as sepsis (including bacteraemia), meningitis, pneumonia, osteomyelitis, cellulitis, gastroenteritis with dehydration, complicated urinary tract infection (positive urine culture result and systemic effects such as fever), and viral respiratory tract infections complicated by hypoxia (for example, bronchiolitis). Studies restricted to one specific serious infection (bacteraemia or meningitis) were not selected for this paper but will be reported separately.

We selected studies if they reported sufficient data to allow construction of $2 \times 2$ tables. No language restrictions were applied.

\section{Quality assessment}

Two independent reviewers (AVDB and TH-H) used the QUADAS instrument to assess the quality of selected articles. Any disagreements were resolved by discussion and consensus, if necessary after contacting the authors for clarification. We used spectrum bias and validity of reference standards as exclusion criteria.

Studies selected for analysis were given an A, B, C, or $\mathrm{D}$ rating. We rated studies fulfilling all QUADAS criteria as A; studies with no or unclear total verification with the reference standard or with interpretation of the index feature unblinded to the results of the reference standard as D; and studies without an independent reference standard, with interpretation of the reference standard unblinded to the results of the index feature, or with an unduly long period between recording of the index feature and outcome as C. All other studies were rated $\mathrm{B}$. If data were insufficient to be confident that a criterion had been met, we assessed the criterion as not being met.

\section{Data extraction and analysis}

Data were extracted by one reviewer (AVDB) and checked by a second reviewer $(\mathrm{TH}-\mathrm{H}) ; 2 \times 2$ tables were constructed based on information in the article or from the authors. We then calculated the likelihood ratios for the presence or absence of each feature. Unlike sensitivity and specificity, likelihood ratios make explicit the impact of the test result on the probability of the disease. It is easiest for clinicians to think of a positive result with a likelihood ratio of 2 as making it twice as likely that the patient has the disease. However, this is imprecise as the likelihood ratio applies to the change in odds rather than probability of diseasethat is, the likelihood ratio $\times$ pre-test odds=post-test odds. So to calculate the precise impact of the test result on disease probability, it is necessary first to convert the pre-test probability to odds (pre-test odds=pre-test probability/(1-pre-test probability)) and then after multiplying by the likelihood ratio convert the odds back to probability (post-test probability=post-test odds/(1+post-test odds $))$. 
Table 1|Characteristics of included studies

\begin{tabular}{|c|c|c|c|c|c|c|c|c|}
\hline Study & Design & Setting, country & $\begin{array}{c}\text { No of } \\
\text { participants }\end{array}$ & $\begin{array}{l}\text { \% serious } \\
\text { infection }\end{array}$ & $\begin{array}{l}\text { Quality } \\
\text { rating }\end{array}$ & Age range & Inclusion criteria & Outcome \\
\hline $\begin{array}{l}\text { Andreola } \\
2007^{16}\end{array}$ & $\begin{array}{l}\text { Prospective, } \\
\text { cross sectional, } \\
\text { consecutive }\end{array}$ & $\begin{array}{l}\text { Emergency } \\
\text { department, Italy }\end{array}$ & 408 & 23.0 & C & $<3$ years & $\begin{array}{l}\text { Fever of uncertain source and } \\
\text { increased risk of serious bacterial } \\
\text { infection; namely, all infants aged } \\
7 \text { days to } 3 \text { months with rectal } \\
\text { temperature }>38^{\circ} \mathrm{C} \text { and children } \\
\text { aged } 3-36 \text { months with ill/toxic } \\
\text { appearance or with rectal } \\
\text { temperature }>39.5^{\circ} \mathrm{C}\end{array}$ & $\begin{array}{l}\text { Bacteraemia, sepsis, acute } \\
\text { pyelonephritis, lobar pneumonia, } \\
\text { bacterial meningitis, bone or joint } \\
\text { infections }\end{array}$ \\
\hline
\end{tabular}

\begin{tabular}{|c|c|c|c|c|c|c|c|}
\hline Baker $1993^{37}$ & $\begin{array}{l}\text { Prospective, cross } \\
\text { sectional, } \\
\text { consecutive }\end{array}$ & $\begin{array}{l}\text { Emergency } \\
\text { department, USA }\end{array}$ & 747 & 8.7 & $C$ & 29-56 days & $\begin{array}{l}\text { Temperature (rectal) } \geq 38.2^{\circ} \mathrm{C} \text { and } \\
\text { immunocompetent }\end{array}$ \\
\hline Baker $1999^{38}$ & $\begin{array}{l}\text { Prospective, } \\
\text { cross sectional, }\end{array}$ & $\begin{array}{l}\text { Emergency } \\
\text { department, USA }\end{array}$ & 422 & 10.2 & $C$ & 29-60 days & $\begin{array}{l}\text { Temperature (rectal) } \geq 38.0^{\circ} \mathrm{C} \text { and } \\
\text { immunocompetent }\end{array}$ \\
\hline
\end{tabular}
consecutive

\begin{tabular}{|c|c|c|c|c|c|c|}
\hline $\begin{array}{l}\text { Berger } \\
1996^{39}\end{array}$ & $\begin{array}{l}\text { Prospective, } \\
\text { cross sectional, } \\
\text { consecutive }\end{array}$ & $\begin{array}{l}\text { Emergency } \\
\text { department, } \\
\text { Netherlands }\end{array}$ & 138 & 23.9 & B & $\begin{array}{l}2 \text { weeks } \\
-1 \text { year }\end{array}$ \\
\hline $\begin{array}{l}\text { Bleeker } \\
2007^{17}\end{array}$ & $\begin{array}{l}\text { Prospective, } \\
\text { cross sectional, } \\
\text { consecutive }\end{array}$ & $\begin{array}{l}\text { Emergency } \\
\text { department, } \\
\text { Netherlands }\end{array}$ & 381 & 26.0 & $D$ & $\begin{array}{l}1-36 \\
\text { months }\end{array}$ \\
\hline
\end{tabular}

\begin{tabular}{|c|c|c|c|c|c|c|c|c|}
\hline $\begin{array}{l}\text { Bonadio } \\
1993^{40}\end{array}$ & $\begin{array}{l}\text { Prospective, } \\
\text { cross sectional; } \\
\text { consecutive }\end{array}$ & $\begin{array}{l}\text { Emergency } \\
\text { department, USA }\end{array}$ & 534 & 4.5 & $\mathrm{D}$ & 4-8 weeks & $\begin{array}{l}\text { Temperature (rectal) } \geq 38^{\circ} \mathrm{C} \text { at } \\
\text { triage, previously healthy }\end{array}$ & $\begin{array}{l}\text { Bacterial meningitis, bacteraemia, } \\
\text { urinary tract infection, salmonella } \\
\text { enteritis, osteomyelitis, septic } \\
\text { arthritis }\end{array}$ \\
\hline $\begin{array}{l}\text { Galetto- } \\
\text { Lacour } \\
2001^{19}\end{array}$ & $\begin{array}{l}\text { Prospective, } \\
\text { cross sectional }\end{array}$ & $\begin{array}{l}\text { Emergency } \\
\text { department, } \\
\text { Switzerland }\end{array}$ & 124 & 22.6 & $\mathrm{D}$ & $\begin{array}{l}7 \text { days } \\
-36 \text { months }\end{array}$ & $\begin{array}{l}\text { Temperature (rectal) }>38.0^{\circ} \mathrm{C} \text { and } \\
\text { no localising signs of infection } \\
\text { from history or physical } \\
\text { examination }\end{array}$ & $\begin{array}{l}\text { Bacteraemia, pyelonephritis, lobar } \\
\text { pneumonia, meningitis, } \\
\text { osteoarthritis }\end{array}$ \\
\hline $\begin{array}{l}\text { Galetto- } \\
\text { Lacour } \\
2003^{20}\end{array}$ & $\begin{array}{l}\text { Prospective, } \\
\text { cross sectional }\end{array}$ & $\begin{array}{l}\text { Emergency } \\
\text { department, } \\
\text { Switzerland }\end{array}$ & 99 & 29.3 & $\mathrm{D}$ & $\begin{array}{l}7 \text { days } \\
-36 \text { months }\end{array}$ & $\begin{array}{l}\text { Temperature (rectal) }>38^{\circ} \mathrm{C} \text { and } \\
\text { without localising signs of } \\
\text { infection in history or at physical } \\
\text { examination }\end{array}$ & $\begin{array}{l}\text { Bacteraemia, pyelonephritis, lobar } \\
\text { pneumonia, meningitis, } \\
\text { osteoarthritis }\end{array}$ \\
\hline $\begin{array}{l}\text { Galetto- } \\
\text { Lacour } \\
2008^{21}\end{array}$ & $\begin{array}{l}\text { Prospective, } \\
\text { cross sectional }\end{array}$ & $\begin{array}{l}\text { Emergency } \\
\text { department, } \\
\text { Switzerland }\end{array}$ & 202 & 26.7 & $\mathrm{D}$ & $\begin{array}{l}7 \text { days } \\
-36 \text { months }\end{array}$ & $\begin{array}{l}\text { Temperature (rectal) }>38.0^{\circ} \mathrm{C} \text { and } \\
\text { without localising signs of } \\
\text { infection in history or at physical } \\
\text { examination }\end{array}$ & $\begin{array}{l}\text { Bacteraemia, pyelonephritis, lobar } \\
\text { pneumonia, meningitis, } \\
\text { osteoarthritis }\end{array}$ \\
\hline Garra $2005^{18}$ & $\begin{array}{l}\text { Prospective, } \\
\text { cross sectional, } \\
\text { consecutive }\end{array}$ & $\begin{array}{l}\text { Emergency } \\
\text { department, USA }\end{array}$ & 181 & 21.6 & C & 29-56 days & Temperature $\left(\right.$ rectal) $\geq 38.1^{\circ} \mathrm{C}$ & $\begin{array}{l}\text { Urinary tract infection, } \\
\text { bacteraemia, bacterial meningitis, } \\
\text { pneumonia, bacterial enteritis }\end{array}$ \\
\hline Hsiao $2006^{22}$ & $\begin{array}{l}\text { Prospective, } \\
\text { cross sectional, } \\
\text { consecutive }\end{array}$ & $\begin{array}{l}\text { Emergency } \\
\text { department, USA }\end{array}$ & 429 & 10.3 & $\mathrm{C}$ & $\begin{array}{l}57-180 \\
\text { days }\end{array}$ & Temperature $\left(\right.$ rectal) $>37.9^{\circ} \mathrm{C}$ & Bacteraemia, urinary tract infection \\
\hline $\begin{array}{l}\text { Nademi } \\
2001^{15}\end{array}$ & $\begin{array}{l}\text { Prospective, } \\
\text { cross sectional, } \\
\text { consecutive }\end{array}$ & $\begin{array}{l}\text { Paediatric } \\
\text { assessment unit, } \\
\text { UK }\end{array}$ & 141 & 29.1 & $\mathrm{D}$ & $0-16$ years & Temperature $\geq 38^{\circ} \mathrm{C}$ & $\begin{array}{l}\text { Sepsis, meningitis, toxic shock } \\
\text { syndrome, brain abscess, } \\
\text { pneumonia, urinary tract infection, } \\
\text { ischiorectal abscess, appendicitis }\end{array}$ \\
\hline $\begin{array}{l}\text { Thayyil } \\
2005^{14}\end{array}$ & $\begin{array}{l}\text { Prospective, } \\
\text { cross sectional, } \\
\text { consecutive }\end{array}$ & $\begin{array}{l}\text { Paediatric } \\
\text { department, UK }\end{array}$ & 72 & 11.1 & $\mathrm{D}$ & $\begin{array}{l}1-36 \\
\text { months }\end{array}$ & $\begin{array}{l}\text { Temperature }>39^{\circ} \mathrm{C} \text { without } \\
\text { localising signs }\end{array}$ & $\begin{array}{l}\text { Bacteraemia, bacterial meningitis, } \\
\text { acute pyelonephritis }\end{array}$ \\
\hline $\begin{array}{l}\text { Trautner } \\
2006^{23}\end{array}$ & $\begin{array}{l}\text { Prospective, } \\
\text { cross sectional }\end{array}$ & $\begin{array}{l}\text { Emergency } \\
\text { department, USA }\end{array}$ & 103 & 19.4 & C & $<17$ years & Temperature $($ rectal $) \geq 41.1^{\circ} \mathrm{C}$ & $\begin{array}{l}\text { Bacterial meningitis, sepsis, } \\
\text { bacteraemia, urinary tract } \\
\text { infection, bacterial gastroenteritis, } \\
\text { pneumonia }\end{array}$ \\
\hline
\end{tabular}

Confidence intervals reported are calculated on the basis of the standard error of a proportion using Stata v9.2. ${ }^{12}$ In case of an empty cell in the $2 \times 2$ table, we added 0.5 to the cell to compute likelihood ratios. All studies were categorised according to setting by using
Temperature $\left(\right.$ rectal) $\geq 38.0^{\circ} \mathrm{C}$

measured on the ward

Referred to emergency

department for fever without

source-temperature $\geq 38^{\circ} \mathrm{C}$ for

which no clear focus could be

identified after evaluation by

general practitioner or after history

taking by paediatrician

Bacteraemia, bacterial meningitis, bacterial gastroenteritis, urinary tract infection, pneumonia, aseptic meningitis, cellulitis, abscess

Bacteraemia, bacterial meningitis, bacterial gastroenteritis, urinary tract infection, pneumonia, aseptic meningitis, cellulitis, abscess, bone or joint infection

Pneumonia, urinary tract infection, bacteraemia, meningitis, cellulitis, septic arthritis, osteomyelitis, otitis media, bacterial gastroenteritis

Bacterial meningitis, sepsis or bacteraemia, urinary tract infection, pneumonia, bacterial gastroenteritis, osteomyelitis, ethmoiditis

prevalence as a proxy: less than $5 \%$, low prevalence settings; 5-20\%, intermediate; and more than 20\%, high. We report both the pre-test and post-test probabilities of serious infection for each study, choosing the cut-off levels that were most commonly reported 


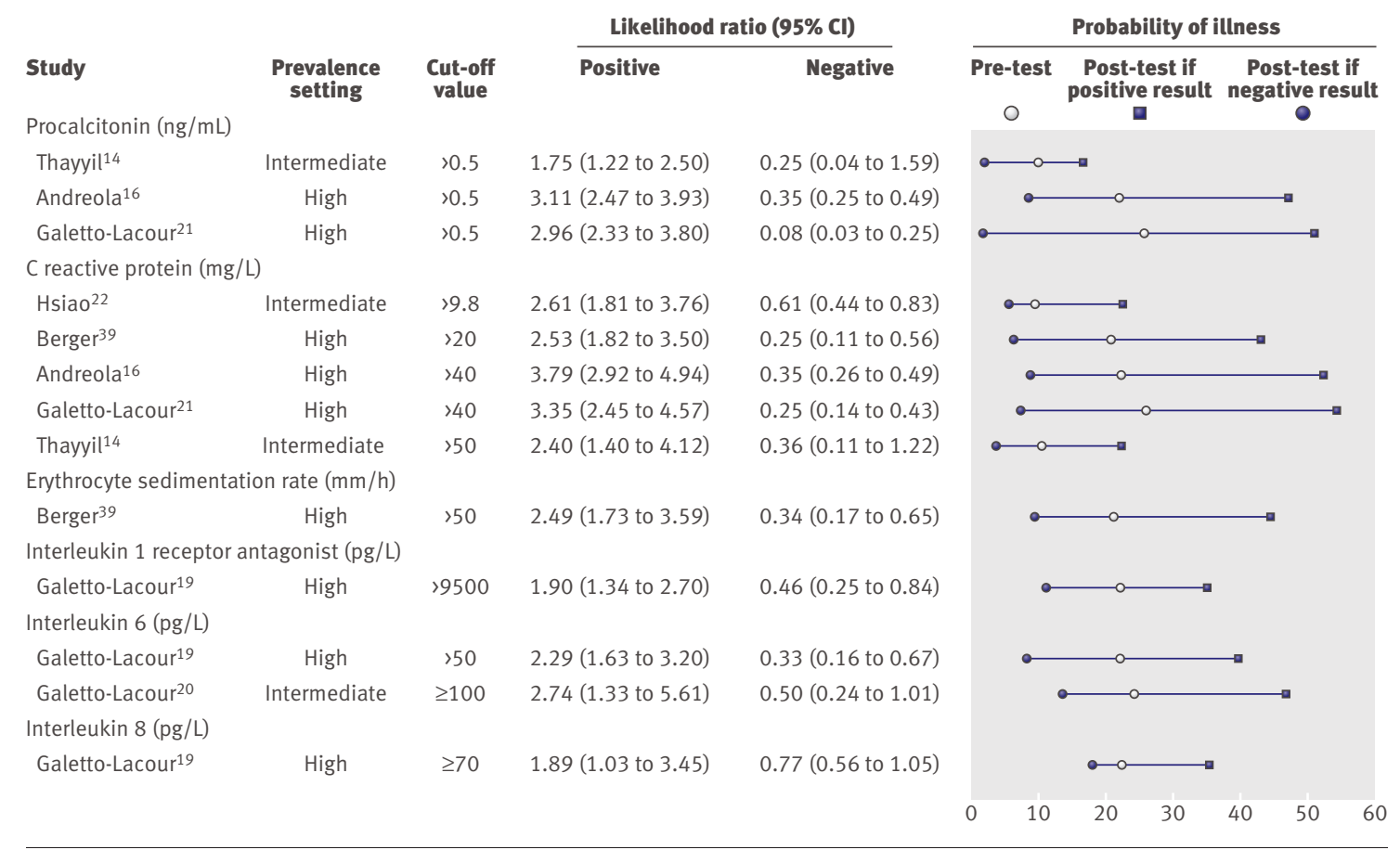

Fig 2| Diagnostic value of inflammatory markers for serious infection in febrile children. Intermediate prevalence 5-20\%; high prevalence $>20 \%$

across studies, and we report the results from each study once only. We show the change in probability of disease after applying the test. The probability of disease before testing equals the prevalence of serious infections in that study, the probability of disease after a positive test result equals the positive predictive value, and the probability of disease after a negative test result equals $1-$ negative predictive value.

Meta-analysis was carried out when at least four different studies were available for a particular laboratory test, using the bivariate random effects method in Stata v9.2, which measures and accounts for any statistical heterogeneity in sensitivity and specificity between studies on the logit scale. We used a minimum of four studies, for a reliable estimate of the correlation between sensitivity and specificity. No imputation of empty cells was applied here as this is accounted for in the method. We did not include overlapping data in the meta-analysis, by selecting only one cut-off value for each study. In addition, since some of the results reported by Galetto-Lacour 2001 and 2003 were included in Galetto-Lacour 2008, we selected the 2008 publication when available and used the other studies only for those tests that were not reported in the 2008 paper.

For $\mathrm{C}$ reactive, procalcitonin, and white blood cell count, some studies reported sensitivity and specificity at multiple thresholds. We pooled these data using the bivariate method of Dukic and Gatsonis, ${ }^{13}$ which is an extension of the usual bivariate method but allows the use of multiple threshold values from each study. The method was implemented in $\mathrm{R}$, with point wise confidence intervals for the sensitivity at a given threshold calculated by simulation.

\section{RESULTS}

The electronic search identified 1860 articles (fig 1). An additional 79 articles were identified in the snowballing strategy. In total, 255 articles were selected for review in full text, of which 36 met the selection criteria. Twenty one of these studies focused on clinical features only or were restricted to specific disease outcomes (for example, meningitis) and so were not included in the analysis reported here. In addition, one study was excluded because the $2 \times 2$ tables could not be constructed, despite the authors being contacted. Table 1 shows the full details of the 14 articles reporting on 13 different studies.

The quality of the 14 articles was modest (see web extra annex 2): none received an A rating. One was rated $B$, six were rated $C$, and seven were rated $D$. Only one study explicitly mentioned blind reading of the reference standard; this item was scored as unclear in eight studies. Only three studies reported indeterminate or intermediate results.

Most of the studies were carried out in emergency departments, with one study done in a paediatric department $^{14}$ and one in a paediatric assessment unit. ${ }^{15}$ All studies selected participants on the presence of fever. The median prevalence of serious infection was $20.5 \%$ (range $4.5-29.3 \%$ ). The age of eligible children also varied among the studies, with four studies including infants only ( $\leq 3$ months) and two studies including older participants, up to 16 years of age. The reported outcomes included bacteraemia (14 studies), sepsis (four), meningitis (13, bacterial only in eight cases), pneumonia (11), and urinary tract infection (14), and in some cases additional infections such as bone or joint infections (eight), bacterial 


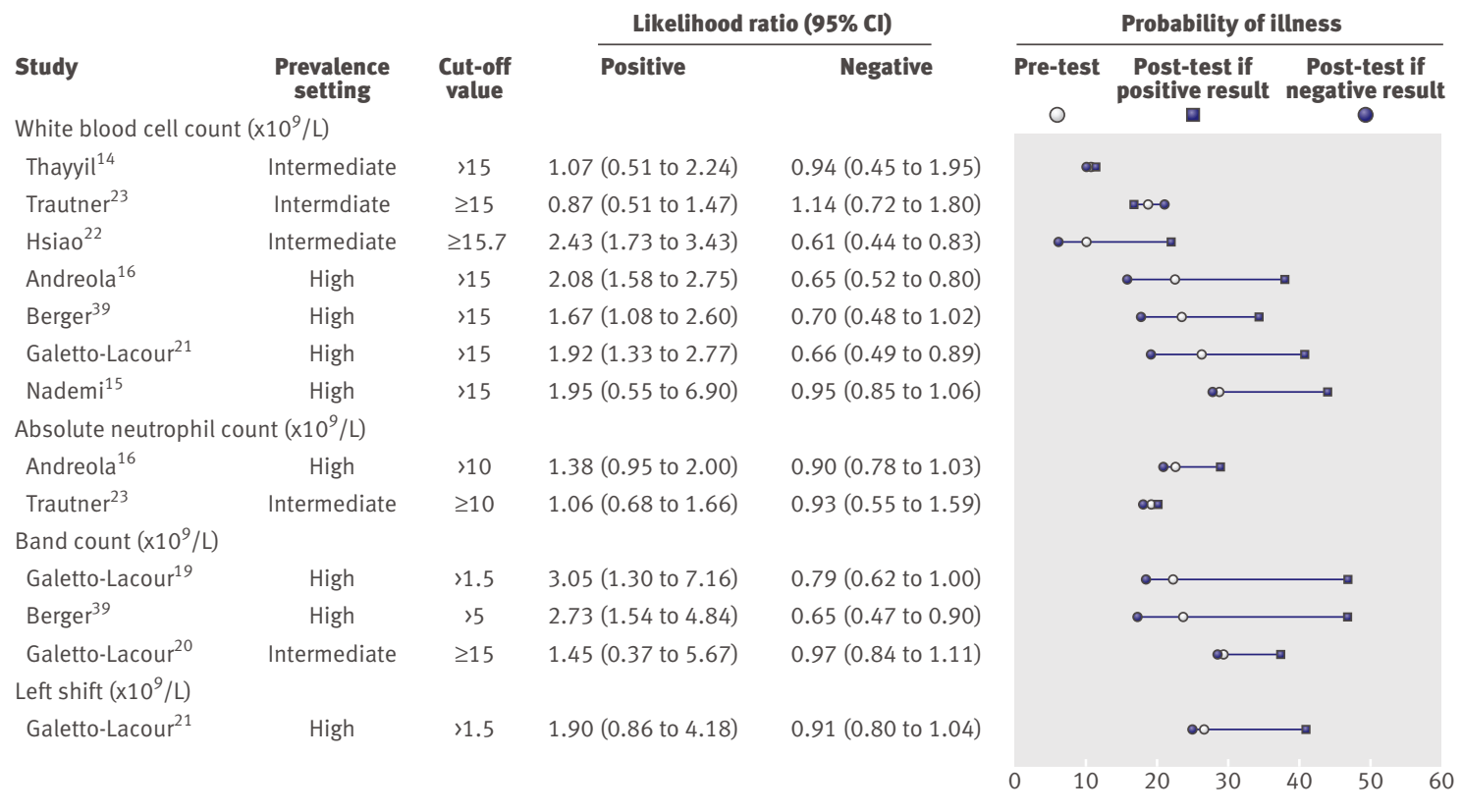

Fig 3 | Diagnostic value of white blood cell counts for serious infection in febrile children. Intermediate prevalence $5-20 \%$; high prevalence $>20 \%$

gastroenteritis (seven), cellulitis (three), and abscess (three). The reference standards used to establish the final diagnoses varied little: blood culture was used in all studies reporting bacteraemia, cerebrospinal fluid analysis and culture was used in all studies reporting meningitis, and chest radiography was used in 10 of 11 studies reporting pneumonia. Of the 14 studies that included urinary tract infection, four added a dimercaptosuccinic acid (DMSA) scan to a urine culture. Of the four studies that reported sepsis, three used clinical features suggestive of systemic response to infection in addition to blood culture.

The laboratory tests measured $\mathrm{C}$ reactive protein (five studies), procalcitonin (three), erythrocyte sedimentation rate (one), interleukins (two), white blood cell count (seven), absolute neutrophil count (two), band count (three), and left shift (one).

\section{Inflammatory markers}

Figure 2 shows that all the inflammatory markers assessed offer important diagnostic information, although the interleukin tests performed less well than the $\mathrm{C}$ reactive protein and procalcitonin tests. The positive likelihood ratios for the procalcitonin test ranged from 1.75 to 3.11 and the negative likelihood ratios ranged from 0.08 to 0.35 . The positive likelihood ratios for the $\mathrm{C}$ reactive protein test ranged from 2.40 to 3.79 and the negative likelihood ratios ranged from 0.25 to 0.61 . The positive likelihood ratios for the interleukin tests ranged from 1.89 to 2.74 and the negative likelihood ratios ranged from 0.33 to 0.77 .

Six studies included more selected patient populations - that is, children with fever without source, either referred ${ }^{1617}$ or not referred. ${ }^{1419-21}$ All three of the studies that evaluated procalcitonin concerned children with fever without a source, whereas for $\mathrm{C}$ reactive protein this population was used in three of five studies and for white blood cell count in three of seven studies. The limited number of studies did not allow formal statistical testing for differences in diagnostic value between these groups.

\section{White blood cell counts}

Figure 3 shows that white blood cell count assays provide less diagnostic value than tests for either $\mathrm{C}$ reactive protein or procalcitonin. They provide minimal diagnostic value in ruling out serious infection: the minimum negative likelihood ratio was 0.61 , with wide 95\% confidence intervals in most studies crossing unity. They provided some diagnostic value for ruling in serious infection, with positive likelihood ratios ranging from 0.87 to 2.43. Although some studies reported imprecise results with wide confidence intervals, two studies included over 400 children and therefore provide the most precise estimates: Hsiao et al ${ }^{22}$ reported a positive likelihood ratio of 2.43 (95\% confidence interval 1.73 to 3.43 ) and negative likelihood ratio of 0.61 (0.44 to 0.83 ) for white blood cell counts of $15 \times 10^{9} / \mathrm{L}$ or more, and Andreola et al ${ }^{16}$ reported a positive likelihood ratio of 2.08 (1.58 to 2.75) and a negative likelihood ratio of 0.65 (0.52 to 0.80$)$ for white blood cell counts greater than $15 \times 10^{9} / \mathrm{L}$. Strikingly, one study reported paradoxical results for white blood cell counts: the likelihood of serious infection was lower in children with a white blood cell count of $15 \times 10^{9} / \mathrm{L}$ or more. ${ }^{23}$ The band count seems the best performing white blood cell marker, with two studies reporting a positive likelihood ratio of around 3 , but the rule out value was still poor (with the $95 \%$ confidence intervals for a negative likelihood ratio in two of the three studies including unity). One study showed that white blood cell count did not offer additional 


\author{
Study \\ Thayyil $^{14}$ \\ $C$ reactive protein $>50 \mathrm{mg} / \mathrm{L}$ \\ Procalcitonin $>2 \mathrm{ng} / \mathrm{mL}$ \\ White blood cell count $>15 \times 10^{9} / \mathrm{L}$ \\ Combined tests \\ Galetto-Lacour $^{19}$ \\ Procalcitonin $>0.9 \mathrm{ng} / \mathrm{mL}$ \\ C reactive protein $>40 \mathrm{mg} / \mathrm{L}$ \\ White blood cell count $>15 \times 10^{9} / \mathrm{L}$ \\ Procalcitonin or $\mathrm{C}$ reactive protein \\ Procalcitonin or white blood cell count \\ Galetto-Lacour ${ }^{20}$ \\ Band count $\geq 15 \times 10^{9} / \mathrm{L}$ \\ White blood cell count $\geq 15 \times 10^{9} / \mathrm{L}$ \\ Band count or white blood cell count
}

\begin{tabular}{lc}
\multicolumn{2}{c}{ Likelihood ratio $(\mathbf{9 5 \%} \mathbf{~ C l})$} \\
\hline Negative & Positive \\
$0.36(0.11$ to 1.22$)$ & $2.40(1.40$ to 4.12$)$ \\
$0.58(0.29$ to 1.17$)$ & $3.56(1.42$ to 8.92$)$ \\
$0.94(0.45$ to 1.95$)$ & $1.07(0.51$ to 2.24$)$ \\
$0.52(0.26$ to 1.05$)$ & $10.67(2.90$ to 39.30$)$ \\
& \\
$0.09(0.02$ to 0.35$)$ & $4.24(2.87$ to 6.28$)$ \\
$0.14(0.05$ to 0.42$)$ & $3.57(2.47$ to 5.17$)$ \\
$0.42(0.24$ to 0.72$)$ & $2.96(1.89$ to 4.63$)$ \\
$0.05(0.01$ to 0.37$)$ & $2.89(2.16$ to 3.87$)$ \\
$0.03(0.00$ to 0.43$)$ & $2.61(2.01$ to 3.39$)$ \\
$0.97(0.84$ to 1.11$)$ & $1.45(0.37$ to 5.67$)$ \\
$0.65(0.44$ to 0.97$)$ & $2.01(1.18$ to 3.42$)$ \\
$0.63(0.41$ to 0.96$)$ & $1.93(1.18$ to 3.17$)$
\end{tabular}

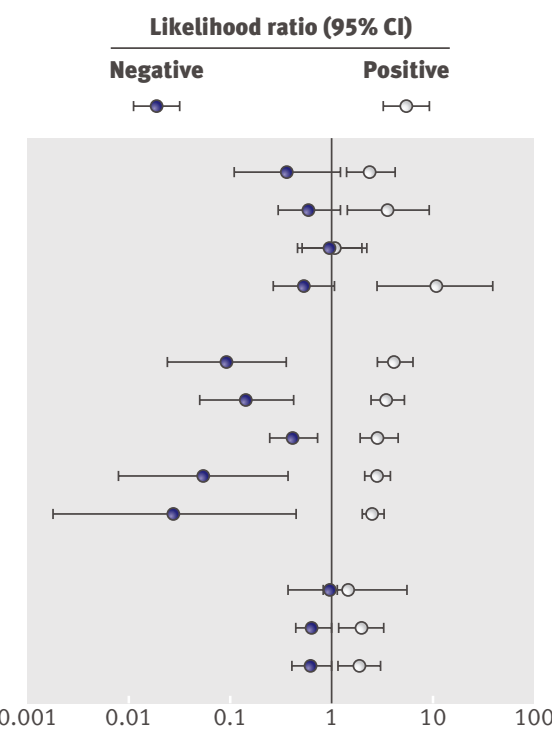

Likelihood ratio $(95 \% \mathrm{Cl})$

Oे

Fig 4 | Likelihood ratios of individual and combination of inflammatory markers and white blood cell counts for serious infection

information over procalcitonin and $\mathrm{C}$ reactive protein in a multivariable logistic regression analysis. ${ }^{21}$

\section{Added value of combinations of blood tests and clinical features}

In general, combinations of blood tests provided little additional diagnostic value over the individual tests, and all confidence intervals of the combinations largely overlapped with those of the individual tests (fig 4).

Figure 5 reports the diagnostic value of clinical prediction rules, which included blood test results as well as clinical features and other investigations (web extra annex 3 reports the precise cut-offs values applied). All studies reporting prediction rules included selected patient populations - that is, children with fever without a source.

The best performing prediction rule by GalettoLacour et al 2008 achieved a positive likelihood ratio of $4.92(95 \%$ confidence interval 3.26 to 7.43$)$ and a negative likelihood ratio of 0.07 (0.02 to 0.27$)$ and involved urine dipstick testing as well as measuring $\mathrm{C}$ reactive protein and procalcitonin (fig 4$).{ }^{21}$ This rule was complicated as it involved calculating a score on the basis of the actual levels of $\mathrm{C}$ reactive protein and procalcitonin, but both the rule in and the rule out potential was good, a high score increasing the likelihood of a serious infection from $27 \%$ to $64 \%$ and a score below the threshold decreasing it to $2 \%$. This rule was recently validated in an independent dataset and was found to maintain its diagnostic value. ${ }^{24}$

The clinical prediction rule reporting the highest positive likelihood ratio 10.67 (2.90 to 39.30$)$ by Thayyil et al, which required levels above threshold on three blood tests (procalcitonin $>2 \mathrm{ng} / \mathrm{mL}, \mathrm{C}$ reactive protein $>50 \mathrm{mg} / \mathrm{L}$, and white blood cell count $>15 \times 10^{9} / \mathrm{L}$ ) lacked rule-out value (negative likelihood ratio $0.52,0.25$ to 1.05$).{ }^{14}$
The only clinical feature explicitly considered in these two best performing prediction rules was fever, which was an inclusion criterion for all the studies reported here. Neither study reported validation or other metrics for performance of the prediction rule.

The prediction rule reported by Bleeker et $\mathrm{al}^{17}$ gives an estimate of the added value that blood tests provide for patients testing positive or negative to a series of clinical features. This suggests that blood testing provides greater ability to rule out serious infection in children at higher risk based on clinical features. In these children, results of a combination of white blood cell count, $\mathrm{C}$ reactive protein, and urinalysis will lower the probability from $42 \%$ to $15 \%$ when the test result is negative, but the probability is not increased substantially when the test result is positive (54\%). On the other hand, in patients testing negative on the clinical prediction rule and therefore at lower risk of serious infection, the blood tests moderately lower the probability (from $12 \%$ to $4 \%$ ) if the results are negative and moderately increase the probability if positive (to $31 \%$ ). For this clinical prediction rule, a goodness of fit was reported (Hosmer-Lemeshow test for the laboratory model $\mathrm{P}=0.3$ ), the area under the curve for the clinical and laboratory model was 0.86 (95\% confidence interval 0.82 to 0.90$)$. This rule was not validated in an independent dataset (the clinical part of the prediction rule was derived in the merged derivation and validation sets).

For completeness figure 5 also reports four clinical prediction rules that include more invasive investigations as well as blood tests and clinical assessment (cerebrospinal fluid variables and chest radiography). These prediction rules, such as the Philadelphia protocol and Milwaukee protocol, are usually applied in infants aged less than 3 months presenting to the emergency department with fever. The plots show they provide little diagnostic value in ruling in serious infection (positive likelihood ratio ranging from 1.27 to 1.70 ) but 


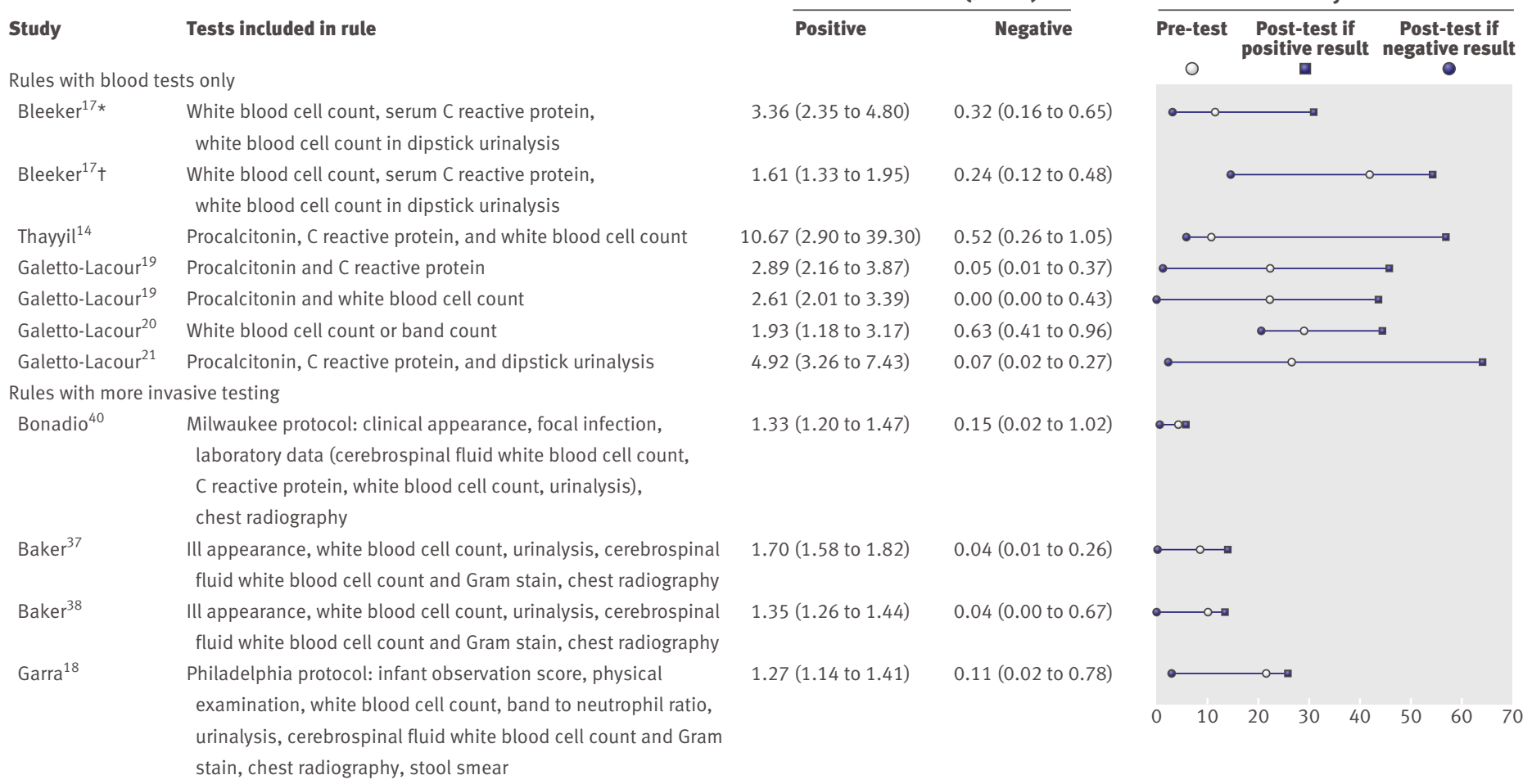

Fig 5 Prediction rules for serious infection in febrile children, combining $\mathrm{C}$ reactive protein, white blood cell count, and procalcitonin with clinical features. *Patients with negative result on clinical prediction rule. †Patients with positive result on clinical prediction rule. See web extra annex 3 for details of cut-off points applied

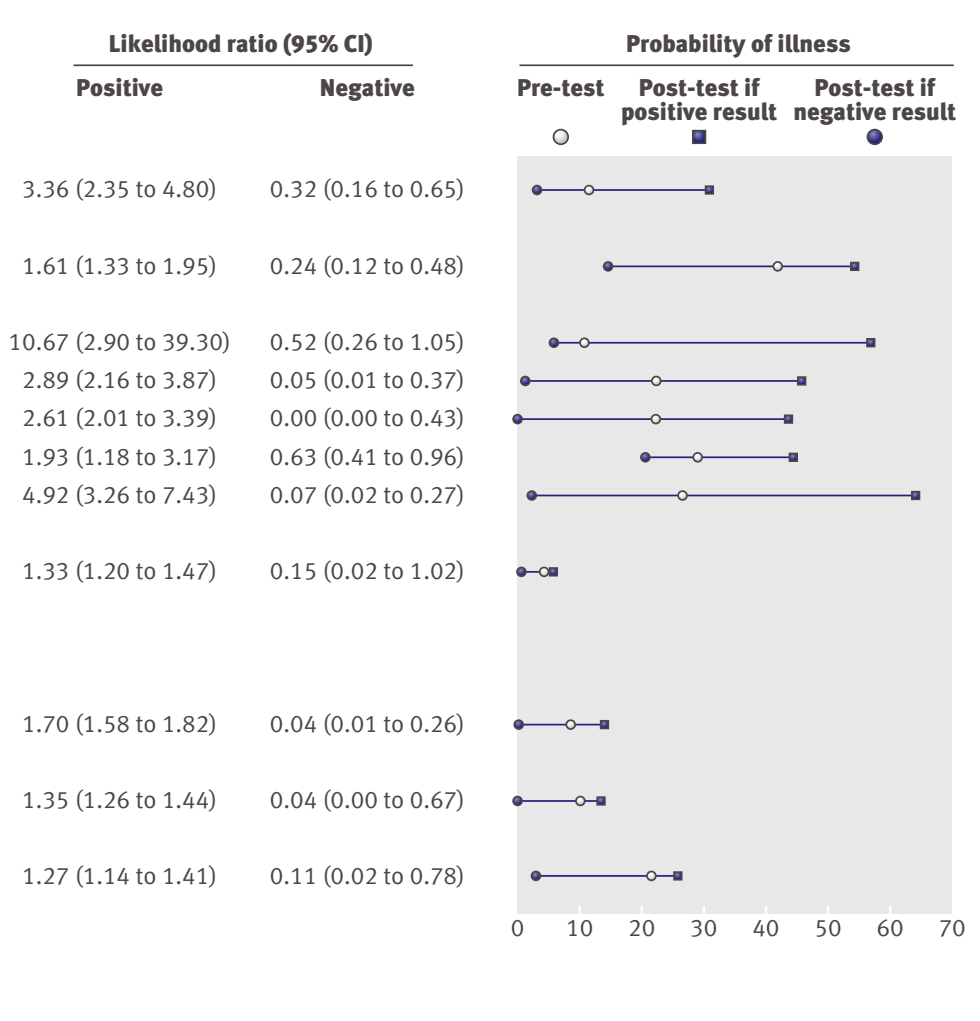




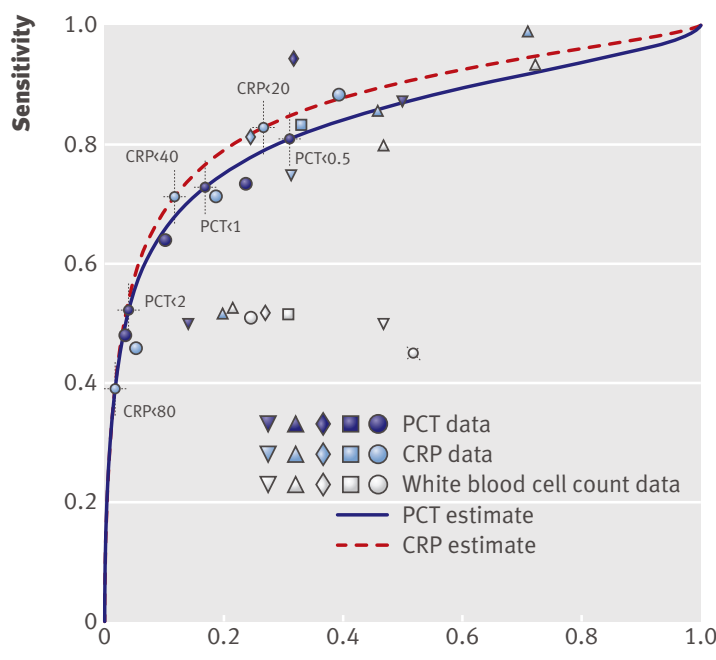

1-specificity

Fig 6 | Summary receiver operating characteristic curves for $C$ reactive protein (CRP) and procalcitonin (PCT) levels for serious infection. Circles=Andreola $2007^{16}$, squares=Berger $1996^{39}$, diamonds=Galetto-Lacour $2008^{21}$, triangles=Hsiao $2006^{22}$, inverted triangles=Thayyill $2005^{14}$

whereas the two other studies reported no statistical testing.

\section{DISCUSSION}

In this systematic review few studies assessed the usefulness of blood tests in identifying serious infection in children presenting to an emergency setting, despite it being an endemic clinical activity in all health systems. The studies we did find were of modest methodological quality and none had been carried out in a low prevalence primary care setting. Moreover, it was difficult to extract the diagnostic added value of testing - that is, in what clinical situations testing is likely to contribute substantially to diagnostic decision making - on the basis of the data reported. Few studies had made explicit the asymmetry of diagnostic value in ruling in and ruling out serious infections, and most reported findings in terms of sensitivity and specificity, which provide little useful information to clinicians interested in the diagnostic value of tests in making clinical decisions.

However, the data suggest that: the tests providing most diagnostic value in feverish children are $\mathrm{C}$ reactive protein and procalcitonin, with no clear evidence from our data that one is better than the other; the optimal cut-off point for $\mathrm{C}$ reactive protein and procalcitonin depends on whether the main clinical focus is ruling in or ruling out serious infection, and the best performing clinical prediction rule uses the actual level to derive a predictive score; and white blood cell indicators probably provide some diagnostic value in ruling in serious infection, but less than the inflammatory markers, and have no value at ruling it out.

Although tests for $\mathrm{C}$ reactive protein and procalcitonin have similar diagnostic properties they might be of different value at different points in the course of illness, as theoretically procalcitonin levels increase earlier than those for $\mathrm{C}$ reactive protein. This is supported by the inclusion of both $\mathrm{C}$ reactive protein and procalcitonin in the best performing clinical prediction rule, although it is unclear whether doing both tests is a cost effective approach.

The results of an earlier review, which was limited to $\mathrm{C}$ reactive protein in children with fever, used slightly different methods but provided similar results: pooled positive likelihood ratio 3.64 (95\% confidence interval 2.99 to 4.43 ) and negative likelihood ratio 0.29 (0.22 to 0.40 ) compared with a positive likelihood ratio of 3.15 (2.67 to 3.71) and a negative likelihood ratio of 0.33 (0.22 to 0.49$)$ in our study. ${ }^{4}$ Other reviews are less comparable because they included both adults and children $^{5-725}$ or used different outcomes. ${ }^{5925}$

\section{Robustness of the findings}

The review methodology was robust, involving an extensive search, and we should have identified all existing good quality studies, which in aggregate included 3981 children.

The reliability of the data is limited by the methodological quality of the studies included in the review, but the modest QUADAS scores reported in part reflect the limitations of undertaking pragmatic studies in a clinical setting. The ideal diagnostic accuracy study would include all eligible patients consecutively, carry out the same index test and reference standard in all patients identically, and read both tests blinded from each other. It is difficult to meet the highest methodological standard for confirming the final diagnosis in a study in routine practice where it is not possible for all children included to have a full investigation. Even so, the quality of the reporting of the methodology of many of the studies was not optimal, although several $\mathrm{C}$ rated studies met the criterion of as good as can be done in routine practice. The importance of large scale pragmatic studies should not be down rated by setting quality criteria that are not feasible. However, the fact that all the studies identified were done on populations of febrile children in settings where serious infection was relatively common (typically 1 in 5 children had serious infection) does limit generalisation to primary

Table 2|Meta-analyses results of diagnostic value of specific tests in febrile children

\begin{tabular}{lccccc} 
& No of studies/ & \% sensitivity & \% specificity & & \multicolumn{2}{c}{ Likelihood ratio $(95 \% \mathrm{Cl})$} \\
\cline { 5 - 6 } Test & No of children & $(95 \% \mathrm{Cl})$ & $(95 \% \mathrm{Cl})$ & Positive & Negative \\
C reactive protein & $5 / 1379$ & $75.1(62.7$ to 84.5$)$ & $76.1(71.0$ to 80.6$)$ & $3.15(2.67$ to 3.71$)$ & $0.33(0.22$ to 0.49$)$ \\
\hline Invasive protocols & $4 / 1884$ & $98.2(94.5$ to 99.4$)$ & $29.9(23.5$ to 37.3$)$ & $1.40(1.27$ to 1.55$)$ & $0.06(0.02$ to 0.19$)$ \\
\hline
\end{tabular}


care settings where typically 1 in 150 children have a serious infection. ${ }^{26}$

\section{Comparison with developing countries}

Our review excluded studies from developing countries because of differences in prevalence; microbiological causes; comorbidities, such as HIV and malnutrition; and more advanced stage of disease at presentation. For these reasons, the diagnostic characteristics of laboratory tests in these settings are likely to be different and should be treated separately.

In general, focus is on clinical signs and symptoms. The World Health Organization has issued the integrated management of childhood illness guidelines to improve recognition and treatment of the five most important illnesses in children: pneumonia, diarrhoea, malaria, measles, and malnutrition. The guidelines emphasise triage based on clinical signs and symptoms, and consequent treatment at a local facility or referral to a regional facility. The guidelines currently do not include specific recommendations on laboratory tests.

\section{Strategic implications}

The evidence base for investigations in children needs strengthening. One of the problems is that most of the studies done to date do not reflect the way the investigation is carried out in practice and often provide little evidence of the added value of different (and serially applied) diagnostic strategies at each stage in the decision making process. Our previous review of the diagnostic value of presenting symptoms and signs showed a substantial diagnostic gap between the predictive value achievable by clinical features without further investigation and the threshold of risk of serious infection that most hospital clinicians would wish to apply to justify hospital admission. ${ }^{1}$ This gap is currently filled by the application of poorly defined clinical "gut feeling" and similarly poorly defined strategies for diagnostic safety netting, ${ }^{27}$ so perhaps it is not surprising that missed cases of serious infection through failed investigations remain common. ${ }^{28}$ In addition, clinicians may have a low threshold for immediate prescription of antibiotics, especially in young children, to avoid missing a serious infection. ${ }^{2930}$

Providing robust evidence to help parents and clinicians differentiate children with serious infections from those with minor illnesses is important for children's health services. It is paradoxical that acute infections continue to generate such large numbers of patient consultations (in primary and secondary care), yet the incidence of serious infections has declined, partly as a result of vaccination. ${ }^{31}$ With increased pressures on health service resources, more robust evidence is needed to identify those few children who need referral or admission. At present up to one third of short stay admissions in infants are for minor illnesses. ${ }^{32}$

The evidence presented here suggests that the role of inflammatory markers is a key issue, but the potential symbiotic value of recording vital signs must also be assessed. ${ }^{33}$ As such, studies in primary care are needed to determine the diagnostic value of point of care testing for $\mathrm{C}$ reactive protein and procalcitonin in combination with clinical signs and vital signs (as well as their feasibility, acceptability, and cost effectiveness). Such studies are, however, difficult to design because of the large sample sizes involving many practices and doctors, and consequent large budgets. In addition, a diagnostic trial could evaluate different diagnostic strategies in primary and secondary care, with risk stratification based on clinical features and vital signs, and laboratory testing (preferably point of care) in selected patients. The trial could evaluate outcomes such as number of referrals to secondary care, further investigations in secondary care, admission to hospital, missed or delayed diagnosis of a serious infection, prescription of antibiotics, as well as cost effectiveness of different strategies.

\section{Immediate clinical implications}

This review provides evidence that measuring the white blood cell count provides limited diagnostic help in identifying serious infection in children. In a primary care setting, where taking blood is invasive and likely to be of high marginal cost, no case exists for its use. The inflammatory markers have more diagnostic value but the low likelihood of serious infection in primary care means that whatever cut-off value is applied the test result is unlikely to change the probability of serious infection to the extent that it would impact on a clinical decision to treat, further investigate, or admit to hospital. Moreover, this review did not identify any studies that directly assessed the diagnostic value of either white blood cell count or inflammatory markers in identifying serious childhood infection in primary care.

The situation is somewhat different in a hospital emergency department or a general practice out of hours assessment centre, as the children presenting are more likely to have serious infection or other serious illness. The higher pre-test probability of serious disease means that the test results will have a greater absolute effect on post-test probabilities. However, measurement of $\mathrm{C}$ reactive protein and procalcitonin will better inform clinical decision making than the white blood cell count in diagnosing serious infection, as long as appropriate thresholds are applied. Combining blood tests-that is, $\mathrm{C}$ reactive protein and white blood cell count-seems not very helpful. At present the test for $\mathrm{C}$ reactive protein is cheaper and easier to carry out at point of care than the test for procalcitonin, thus making it the preferred choice. In addition, point of care tests for $\mathrm{C}$ reactive protein have been shown to generally correlate well with classic laboratory tests in studies in primary care and emergency departments. ${ }^{34-36}$

With the exception of the invasive protocols, such as the Milwaukee protocol, that are done routinely in feverish infants and that show great value in excluding serious infections, most clinicians will assess children first and selectively request laboratory tests depending 


\section{WHAT IS ALREADY KNOWN ON THIS TOPIC}

\section{Serious infections in children are rare but can have major consequences}

Some laboratory tests, such as for white blood cell count, are routinely measured in some settings in acutely ill children

\section{WHAT THIS STUDY ADDS}

$C$ reactive protein and procalcitonin may be useful measures, but different cut-off values should be used for ruling in or ruling out serious infections

White blood cell counts are less useful

No evidence from primary care was identified

on the assessment. Children testing positive on a clinical prediction rule (with signs and symptoms suggestive of serious infection) or children with fever without an apparent source seem to derive most benefit from laboratory testing. An individualised approach for children with fever is necessary to optimise diagnostic investigations and treatment in the different emergency care settings. The potential impact of testing for $\mathrm{C}$ reactive protein on clinical decision making and the need to avoid setting a fixed cut-off point for interpreting test results, is probably best shown by considering the potential impact of testing feverish children presenting to the emergency department. If their fever is high $\left(>39.5^{\circ} \mathrm{C}\right)$ and the source is not apparent, there is about a 1 in $4(23 \%)$ pre-test risk of the child having a serious infection. A blood $\mathrm{C}$ reactive protein level of $80 \mathrm{mg} / \mathrm{L}$ or more will raise this probability to $72 \%$, usefully informing the decision that further investigation and admission are necessary. However, a level below $80 \mathrm{mg} / \mathrm{L}$ is still associated with a risk of $15 \% .^{16}$ To reduce this risk to $5 \%$ (at which the clinician and parent might be happy to allow a child home with appropriate safety netting), the level would need to be below $20 \mathrm{mg} / \mathrm{L}$. So if the $\mathrm{C}$ reactive protein level is to be used to guide decisions about whether to discharge children from hospital to be observed at home, a much lower threshold must be applied than the one used to guide the decision to investigate further, start treatment, or admit.

We thank Jason Oke for advice on statistical programming and Vanja Dukic for her help with the extended bivariate meta-analysis. ERNIE is an acronym for the European Research Network on recognising serious InfEction. The principal ERNIE investigators are: Marjolein Berger, Frank Buntinx, Tanya Haj-Hassan, Monica Lakhanpaul, David Mant, Henriette Moll, Rianne Oostenbrink, Richard Stevens, Matthew Thompson, Ann Van den Bruel, and Jan Verbakel.

Contributors: AVDB conceived the study, carried out the literature search and analysis, and drafted the manuscript. AVDB is guarantor for the study. MJT conceived the study, carried out the literature search and analysis, and commented on the manuscript. TH-H carried out the literature search and analysis, and co-drafted the manuscript. RS carried out some specific analyses and commented on the manuscript. HM and ML assisted in the literature search and analysis and commented on the manuscript. DM conceived the study, carried out the analysis, and co-drafted the manuscript.

Funding: This study was funded by the Health Technology Assessment project 07/37/05 (Systematic review and validation of clinical prediction rules for identifying children with serious infections in emergency departments and urgent-access primary care) and the National Institute for Health Research's National School for Primary Care Research.
Competing interests: All authors have completed the ICMJE uniform disclosure form at www.icmje.org/coi_disclosure.pdf (available on request from the corresponding author) and declare: no support from any organisation for the submitted work; no financial relationships with any organisations that might have an interest in the submitted work in the previous three years; no other relationships or activities that could appear to have influenced the submitted work.

Ethical approval: Not required.

Copyright: This work was funded by the Health Technology Assessment and is therefore subject to standard arrangements for use of Crown copyright material by other organisations. Data sharing: No additional data available.

1 Van den Bruel A, Haj-Hassan T, Thompson M, Buntinx F, Mant D. Diagnostic value of clinical features at presentation to identify serious infection in children in developed countries: a systematic review. Lancet 2010;375:834-45.

2 Craig JC, Williams GJ, Jones M, Codarini M, Macaskill P, Hayen A, et al. The accuracy of clinical symptoms and signs for the diagnosis of serious bacterial infection in young febrile children: prospective cohort study of 15781 febrile illnesses. BMJ 2010;340:c1594.

3 Cals JW, Butler CC, Hopstaken RM, Hood K, Dinant GJ. Effect of point of care testing for $C$ reactive protein and training in communication skills on antibiotic use in lower respiratory tract infections: cluster randomised trial. BMJ 2009;338:b1374.

4 Sanders S, Barnett A, Correa-Velez I, Coulthard M, Doust J. Systematic review of the diagnostic accuracy of $\mathrm{C}$-reactive protein to detect bacterial infection in nonhospitalized infants and children with fever. J Pediatr 2008;153:570-4.

5 Falk G, Fahey T. C-reactive protein and community-acquired pneumonia in ambulatory care: systematic review of diagnostic accuracy studies. Fam Pract 2009;26:10-21.

6 Van der Meer V, Neven AK, van den Broek PJ, Assendelft WJ. Diagnostic value of $C$ reactive protein in infections of the lower respiratory tract: systematic review. BMJ 2005;331:26.

7 Simon L, Gauvin F, Amre DK, Saint-Louis P, Lacroix J. Serum procalcitonin and $\mathrm{C}$-reactive protein levels as markers of bacterial infection: a systematic review and meta-analysis. Clin Infect Dis 2004;39:206-17.

8 Flood RG, Badik J, Aronoff SC. The utility of serum C-reactive protein in differentiating bacterial from nonbacterial pneumonia in children: meta-analysis of 1230 children. Pediatr Infect Dis / 2008;27:95-9.

9 Mantadakis E, Plessa E, Vouloumanou EK, Karageorgopoulos DE, Chatzimichael A, Falagas ME. Serum procalcitonin for prediction of renal parenchymal involvement in children with urinary tract infections: a meta-analysis of prospective clinical studies. J Pediatr 2009;155:875-81,e1.

10 National Institute for Health and Clinical Excellence. Feverish illness in children: assessment and initial management in children younger than 5 years. NICE, 2007.

11 National Institute for Health and Clinical Excellence. Urinary tract infection in children: diagnosis, treatment and long-term management. NICE, 2007.

12 StataCorp. Stata statistical software [program]. Release 9. StataCorp, 2005.

13 Dukic V, Gatsonis C. Meta-analysis of diagnostic test accuracy assessment studies with varying number of thresholds. Biometrics 2003;59:936-46.

14 Thayyil S, Shenoy M, Hamaluba M, Gupta A, Frater J, Verber IG. Is procalcitonin useful in early diagnosis of serious bacterial infections in children? Acta Paediatr 2005;94:155-8.

15 Nademi Z, Clark J, Richards CG, Walshaw D, Cant AJ. The causes of fever in children attending hospital in the north of England. J Infect 2001;43:221-5.

16 Andreola B, Bressan S, Callegaro S, Liverani A, Plebani M, Da Dalt L. Procalcitonin and $C$-reactive protein as diagnostic markers of severe bacterial infections in febrile infants and children in the emergency department. Pediatr Infect Dis / 2007;26:672-7.

17 Bleeker SE, Derksen-Lubsen G, Grobbee DE, Donders AR, Moons KG, Moll HA. Validating and updating a prediction rule for serious bacterial infection in patients with fever without source. Acta Paediatr 2007;96:100-4

18 Garra G, Cunningham SJ, Crain EF. Reappraisal of criteria used to predict serious bacterial illness in febrile infants less than 8 weeks of age. Acad Emerg Med 2005;12:921-5.

19 Galetto-Lacour A, Gervaix A, Zamora SA, Vadas L, Lombard PR, Dayer JM, et al. Procalcitonin, IL-6, IL-8, IL-1 receptor antagonist and $\mathrm{C}$-reactive protein as identificators of serious bacterial infections in children with fever without localising signs. Eur J Pediatr 2001;160:95-100.

20 Galetto-Lacour A, Zamora SA, Gervaix A. Bedside procalcitonin and $C$-reactive protein tests in children with fever without localizing signs of infection seen in a referral center. Pediatrics 2003;112:1054-60. 
21 Lacour AG, Zamora SA, Gervaix A. A score identifying serious bacterial infections in children with fever without source. Pediatr Infect Dis / 2008;27:654-6.

22 Hsiao AL, Chen L, Baker MD. Incidence and predictors of serious bacterial infections among 57 - to 180 -day-old infants. Pediatrics 2006;117:1695-701.

23 Trautner BW, Caviness AC, Gerlacher GR, Demmler G, Macias CG. Prospective evaluation of the risk of serious bacterial infection in children who present to the emergency department with hyperpyrexia (temperature of 106 degrees F or higher). Pediatrics 2006;118:34-40.

24 Galetto-Lacour A, Zamora SA, Andreola B, Bressan S, Lacroix L, Da Dalt $L$, et al. Validation of a laboratory risk index score for the identification of severe bacterial infection in children with fever without source. Arch Dis Child 2010;95:968-73.

25 Jones AE, Fiechtl JF, Brown MD, Ballew JJ, Kline JA. Procalcitonin test in the diagnosis of bacteremia: a meta-analysis. Ann Emerg Med 2007;50:34-41.

26 Van den Bruel A, Aertgeerts B, Bruyninckx R, Aerts M, Buntinx F. Signs and symptoms for diagnosis of serious infections in children: a prospective study in primary care. Br J Gen Pract 2007;57:538-46.

27 Almond S, Mant D, Thompson M. Diagnostic safety-netting. Br J Gen Pract 2009;59:872-4.

28 Thompson MJ, Ninis N, Perera R, Mayon-White R, Phillips C, Bailey L, et al. Clinical recognition of meningococcal disease in children and adolescents. Lancet 2006;367:397-403.

29 Thompson PL, Spyridis N, Sharland M, Gilbert RE, Saxena S, Long PF, et al. Changes in clinical indications for community antibiotic prescribing for children in the UK from 1996 to 2006: will the new NICE prescribing guidance on upper respiratory tract infections just be ignored? Arch Dis Child 2009;94:337-40.

30 De Jong J, van den Berg PB, Visser ST, de Vries TW, de Jong-van den Berg LT. Antibiotic usage, dosage and course length in children between 0 and 4 years. Acta Paediatr 2009;98:1142-8.
31 Van den Bruel A, Bartholomeeusen S, Aertgeerts B, Truyers C, Buntinx F. Serious infections in children: an incidence study in family practice. BMC Fam Pract 2006;7:23.

32 Saxena S, Bottle A, Gilbert R, Sharland M. Increasing short-stay unplanned hospital admissions among children in England; time trends analysis 97-06. PLoS One 2009;4:e7484.

33 Thompson MJ, Coad N, Harnden A, Mayon-White R, Perera R, Mant D. How well do vital signs identify children with serious infections in paediatric emergency care? Arch Dis Child 2009;94:888-93.

34 Esposito S, Tremolati E, Begliatti E, Bosis S, Gualtieri L, Principi N. Evaluation of a rapid bedside test for the quantitative determination of C-reactive protein. Clin Chem Lab Med 2005;43:438-40.

35 Seamark DA, Backhouse SN, Powell R. Field-testing and validation in a primary care setting of a point-of-care test for $\mathrm{C}$-reactive protein. Ann Clin Biochem 2003;40:178-80.

36 Monteny M, ten Brinke MH, van Brakel J, de Rijke YB, Berger MY. Point-of-care $\mathrm{C}$-reactive protein testing in febrile children in general practice. Clin Chem Lab Med 2006;44:1428-32.

37 Baker MD, Bell LM, Avner JR. Outpatient management without antibiotics of fever in selected infants. N Engl J Med 1993;329:1437-41.

38 Baker MD, Bell LM, Avner JR. The efficacy of routine outpatient management without antibiotics of fever in selected infants. Pediatrics 1999;103:627-31.

39 Berger RM, Berger MY, van Steensel-Moll HA, Dzoljic-Danilovic G, Derksen-Lubsen G. A predictive model to estimate the risk of serious bacterial infections in febrile infants. Eur J Pediatr 1996;155:468-73.

40 Bonadio WA, Hagen E, Rucka J, Shallow K, Stommel P, Smith D. Efficacy of a protocol to distinguish risk of serious bacterial infection in the outpatient evaluation of febrile young infants. Clin Pediatr (Phila) 1993;32:401-4.

Accepted: 6 April 2011 